\title{
Determining the Longissimus lumborum and Psoas major Beef Steak Color Life Threshold and Effect of Postmortem Aging Time Using Meta-analysis
}

\author{
F. Najar-Villarreal ${ }^{1}$, E. A. E. Boyle ${ }^{1 *}$, C. I. Vahl ${ }^{2}$, Q. Kang ${ }^{2}$, J. J. Kastner ${ }^{3}$, J. Amamcharla ${ }^{1}$, and M. C. Hunt ${ }^{1}$ \\ ${ }^{1}$ Department of Animal Sciences and Industry, Kansas State University, Manhattan, KS 66506, USA \\ ${ }^{2}$ Department of Statistics, Kansas State University, Manhattan, KS 66506, USA \\ ${ }^{3}$ Department of Diagnostic Medicine/Pathobiology, Kansas State University, Manhattan, KS 66506, USA \\ *Corresponding author. Email: Iboyle@ksu.edu (E. A. E. Boyle)
}

\begin{abstract}
Using meta-analysis, the color life threshold for beef longissimus lumborum (LL) and psoas major (PM) steaks during retail display (phase 1) and the effect of postmortem aging time (phase 2) on the display color life of LL and PM steaks were determined. In phase 1, data were retrieved from 13 refereed journal articles for LL and 3 refereed journal articles for PM, which included $a^{*}$ and subjective visual scores. The total display day observations for LL and PM were 148 and 27, respectively. Lower bound estimates using a 95\% confidence interval for $a^{*}$ as a threshold for the display color life of LL and PM steaks were 20.24 and 20.99, respectively. For phase 2, data were retrieved from 26 refereed journal articles for LL and 10 referred journal articles for PM, which included $a^{*}$ and postmortem aging time. The total display day observations for LL and PM in phase 2 were 255 and 71, respectively. For LL steaks, the actual postmortem aging time was grouped into 5 categories: 0-7 d, 8-14 d, 15-21 d, 22-28 d, and 29-65 d. Additionally, the postmortem aging time of PM steaks was grouped into 2 categories: $0-7 \mathrm{~d}$ and $8-21 \mathrm{~d}$. The first 21 -d postmortem aging time for LL steaks had the longest color life, with $7 \mathrm{~d}$. Additionally, 22 to $28 \mathrm{~d}$ of postmortem aging time and 29 to $65 \mathrm{~d}$ of postmortem aging time had $5 \mathrm{~d}$ and $4 \mathrm{~d}$, respectively, of color life for LL steaks. The borderline acceptability estimated for PM steaks with 0-7 d and 8-21 of postmortem aging time was $3 \mathrm{~d}$ and $2 \mathrm{~d}$ of color life, respectively. Estimations from this meta-analysis demonstrate that using LL and PM subprimals that have a postmortem aging time of $21 \mathrm{~d}$ or less and $7 \mathrm{~d}$ or less, respectively, would optimize the retail display color life of aerobically packaged steaks.
\end{abstract}

Key words: beef, color life, meta-analysis, postmortem aging time

Meat and Muscle Biology 5(1): 41, 1-11 (2021)

doi: $10.22175 / \mathrm{mmb} .12526$

Submitted 29 April 2021

Accepted 26 August 2021

\section{Introduction}

The meat industry, foodservice, retail businesses, and all individuals in the supply chain that commercialize meat have control of the color life of meat. One important aspect that plays a role in meat discoloration during retail display of aerobically packaged steaks is the time from animal harvest, or postmortem aging time. Colle et al. (2015) concluded that extended postmortem aging time has a strong impact on the color life of various muscles. They also indicated that extended postmortem aging time in USDA Select strip loins longer than $14 \mathrm{~d}$ was detrimental for its color life. The 2010/2011 National Beef Tenderness Survey reported that postmortem aging time for vacuum-packaged subprimals under refrigerated conditions ranged from 1 to $358 \mathrm{~d}$ and from 9 to $67 \mathrm{~d}$ at the retail level and with foodservice, respectively (Guelker et al., 2013). Overall, beef held for extended times under vacuum may exhibit color issues after steaks are cut, aerobically packaged, and displayed at the retail level. According to the 2015 National Beef Tenderness Survey, postmortem aging time of strip loins at retail was shown to vary from 6 to $101 \mathrm{~d}$, with a post-fabrication storage average of $27.2 \mathrm{~d}$ (Martinez et al., 2017). 
By understanding the factors that affect meat color stability when displayed, including the influence of postmortem aging time, the retail display life of fresh meat can be optimized, thus preventing meat waste at the retail level. It is well established that meat color is used by consumers as an indicator of freshness and wholesomeness when selecting their meat purchases (Kropf, 1993). There are several factors that affect the appearance of fresh meat color, including processing, packaging, distribution, and display temperature (Mancini and Hunt, 2005). These variables also affect the rate at which the process of meat discoloration occurs, resulting in revenue loss at the retail level. Discoloration of meat has been extensively researched through objective and subjective methods utilizing instrumental color methodologies and trained panelists, respectively, during shelf-life studies as well as the relationship between them in order to determine color life thresholds (Hunt et al., 2004; Colle et al., 2015; Steele et al., 2016). Visual color scores determined by trained panelists have been associated with a strong correlation with consumers' purchasing intent when beef is not red (Carpenter et al., 2001). As a result, Mancini and Hunt (2005) stated that visual scores determined by a trained panel is the gold standard to know consumer liking responses.

Traditionally, 2 categories - color-stable and colorlabile muscle - have been established based on the biochemical characteristics that affect the color stability of beef muscles (McKenna et al., 2005). The longissimus lumborum (LL) muscle, or strip loin, belongs to the color-stable muscle category and exhibits excellent color stability properties during retail display (Seyfert et al., 2006; Joseph et al., 2012). On the other hand, the psoas major (PM), or tenderloin, a color-labile muscle, has less color life when displayed (Seyfert et al., 2006). Historically, the comparison between these muscles has served as a good model because of the difference in their muscle biochemistry. In addition, the LL and PM are readily accessible at retail owing to their popularity among meat shoppers.

A meta-analysis was used to combine data from several studies in order to develop a single conclusion that has greater statistical power by providing sufficient statistics, where multiple data points are used to provide information about a sample mean and sample variance. To the best of our knowledge, there have been no meta-analyses evaluating the color life of fresh meat in the literature. Therefore, the objective of this study was to determine the color life threshold for LL and PM steaks during retail display using published visual and instrumental color data (phase 1) and the effect of postmortem aging time on the display color life of LL and PM steaks (phase 2).

\section{Materials and Methods}

\section{Meta-analysis}

Phase 1. An electronic literature search was conducted to retrieve studies that have evaluated the effects of display day on LL and PM muscle using spectrophotometers with illuminant A. A literature search was conducted via the Kansas State University Libraries utilizing the Centre for Agriculture and Bioscience International search engine for articles from 2000 to 2020. The search was restricted to studies presented in English in peer-reviewed journals. Visual scores from each experiment for LL were standardized for an 8-point line scale in which $1=$ very bright red, $2=$ bright red, $3=$ dull red, $4=$ slightly dark red, $5=$ moderately dark red, $6=$ dark red to tannish red, $7=$ dark reddish tan, and $8=\tan$ to brown. Additionally, the PM visual color values were used based on a 5point scale in which $1=$ very bright cherry red, $2=$ bright cherry red, $3=$ slightly dark red to tannish red, $4=$ moderately grayish tan to brown, and $5=\tan$ to brown; a score of 3.5 was considered borderline acceptable by the trained panelist (Seyfert et al., 2007). Studies used in this meta-analysis are shown in Table 1. There were 5 identified visual color score thresholds for LL and 3 identified for PM in the literature, and an average was calculated to be used in the model for LL and PM. The response variable "visual score" was based on subjective measurement of color, which included meat color, meat discoloration, and muscle darkening scores that convey the same information and were converted into the same scale. A simple linear transformation was used to rescale visual color scores to fit on a 1- to 8-point line scale. The reported score was divided by the maximum possible score and multiplied by 8 . The same procedure was performed for their SEM. Based on these criteria, the final database resulted in 13 papers for LL and 3 papers for PM, using illuminant $\mathrm{A}$. The total display day observations for $\mathrm{LL}$ and PM were 148 and 27, respectively, and are equal to each data point corresponding to each display day within an experiment within each paper.

Phase 2. Similarly, an electronic literature search was conducted to study the postmortem aging time effect on the color life of LL and PM using illuminant A to assess meat color. The final database resulted in 26 papers for LL and 10 papers for PM. For LL steaks, the actual postmortem aging times were grouped into 
Table 1. Summary of papers using illuminant A used in the regression analysis to predict redness of LL and PM steaks $^{1}$

\begin{tabular}{|c|c|c|c|c|c|c|c|c|c|c|}
\hline Author(s) & Source $^{2}$ & Colorimeter & $\begin{array}{c}\text { Aperture } \\
\text { size }\end{array}$ & Scans $^{3}$ & $\begin{array}{c}\text { Display } \\
\text { days }\end{array}$ & $\begin{array}{c}\text { Steak } \\
\text { thickness }\end{array}$ & $\mathrm{pH}^{4}$ & $\begin{array}{l}\text { Temperature } \\
{ }^{\circ} \mathrm{C}^{5} \\
\end{array}$ & $\begin{array}{c}\text { Lighting } \\
\text { type }^{6}\end{array}$ & Muscle $^{1}$ \\
\hline Steele et al. (2016) & $\mathrm{J}$ & HunterLab MiniScan ${ }^{\mathrm{TM}} \mathrm{EZ}$ & $31.8 \mathrm{~mm}$ & 3 & $0,1,2$ & $2.54 \mathrm{~cm}$ & 5.62 & $1.2^{\circ} \mathrm{C}$ & F, LED & LL \\
\hline Colle et al. (2015) & $\mathrm{J}$ & Hunter MiniScan EZ & $25 \mathrm{~mm}$ & 2 & $0,1,2,3,4$ & $2.54 \mathrm{~cm}$ & 5.62 & $3.0^{\circ} \mathrm{C}$ & $\mathrm{N}$ & LL \\
\hline Kim et al. (2006) & $\mathrm{J}$ & 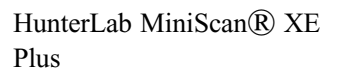 & $2.54 \mathrm{~cm}$ & 3 & $2,9,14$ & $2.54 \mathrm{~cm}$ & 5.85 & $1.0^{\circ} \mathrm{C}$ & $\mathrm{F}$ & LL \\
\hline Rogers et al. (2010) & $\mathrm{J}$ & 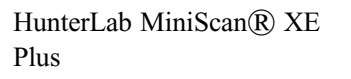 & $2.54 \mathrm{~cm}$ & 3 & $0,2,4$ & $2.54 \mathrm{~cm}$ & NR & $0.9^{\circ} \mathrm{C} \pm 2.3^{\circ} \mathrm{C}$ & $\mathrm{F}$ & LL \\
\hline Grobbel (2008) & $\mathrm{J}$ & $\begin{array}{l}\text { HunterLab MiniScan } 囚 \text { XE } \\
\text { Plus Spectrophotometer }\end{array}$ & $2.54 \mathrm{~cm}$ & 3 & 0,7 & $2.54 \mathrm{~cm}$ & 5.50 & $2.0^{\circ} \mathrm{C}$ & $\mathrm{F}$ & LL \\
\hline Seyfert et al. (2006) & $\mathrm{J}$ & $\begin{array}{l}\text { HunterLab MiniScan } 囚 \text { XE } \\
\text { Plus Spectrophotometer }\end{array}$ & $2.54 \mathrm{~cm}$ & 3 & $\begin{array}{l}0,1,2,3 \\
4,5,6,7\end{array}$ & $2.54 \mathrm{~cm}$ & 5.62 & $1.7^{\circ} \mathrm{C} \pm 3.2^{\circ} \mathrm{C}$ & $\mathrm{F}$ & LL, PM \\
\hline English (2015) & $\mathrm{D}$ & $\begin{array}{l}\text { HunterLab MiniScan } \AA \text { XE } \\
\text { Plus Spectrophotometer }\end{array}$ & $2.50 \mathrm{~cm}$ & 2 & $\begin{array}{l}0,1,2,3 \\
4,5,6\end{array}$ & $2.54 \mathrm{~cm}$ & 5.60 & $2.0^{\circ} \mathrm{C} \pm 1^{\circ} \mathrm{C}$ & $\mathrm{F}$ & LL \\
\hline Mitacek et al. (2018) & $\mathrm{J}$ & 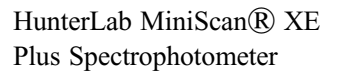 & $2.50 \mathrm{~cm}$ & 3 & $\begin{array}{c}0,1,2,3 \\
4,5,6\end{array}$ & $2.50 \mathrm{~cm}$ & 5.50 & $2.0^{\circ} \mathrm{C} \pm 1^{\circ} \mathrm{C}$ & $\mathrm{F}$ & LL \\
\hline Seyfert et al. (2007) & $\mathrm{J}$ & $\begin{array}{l}\text { HunterLab MiniScan } ® \text { XE } \\
\text { Plus Spectrophotometer }\end{array}$ & $2.54 \mathrm{~cm}$ & 3 & $0,4,7$ & $2.54 \mathrm{~cm}$ & $\begin{array}{l}5.50 \\
5.60\end{array}$ & $0.2^{\circ} \mathrm{C} \pm 3.1^{\circ} \mathrm{C}$ & $\mathrm{F}$ & LL, PM \\
\hline Hutchison (2007) & $\mathrm{D}$ & $\begin{array}{l}\text { HunterLab MiniScan } ® \text { XE } \\
\text { Plus Spectrophotometer }\end{array}$ & $2.54 \mathrm{~cm}$ & 3 & $\begin{array}{c}0,1,2,3 \\
4,5,6\end{array}$ & $2.54 \mathrm{~cm}$ & 5.75 & $2.0^{\circ} \mathrm{C} \pm 5.0^{\circ} \mathrm{C}$ & $\mathrm{F}$ & LL \\
\hline Gonzalez et al. (2009) & $\mathrm{J}$ & $\begin{array}{l}\text { HunterLab MiniScan } 囚 \text { XE } \\
\text { Plus Spectrophotometer }\end{array}$ & $2.54 \mathrm{~cm}$ & 2 & $\begin{array}{l}0,1,2,3 \\
\quad 4,5\end{array}$ & $1.27 \mathrm{~cm}$ & NR & $2.0^{\circ} \mathrm{C} \pm 3.0^{\circ} \mathrm{C}$ & $\mathrm{F}$ & LL \\
\hline Daniel et al. (2009) & $\mathrm{J}$ & $\begin{array}{l}\text { HunterLab MiniScan } ® \text { XE } \\
\text { Plus Spectrophotometer }\end{array}$ & $2.54 \mathrm{~cm}$ & 3 & $\begin{array}{c}0,1,2,3 \\
4,5,6\end{array}$ & $2.54 \mathrm{~cm}$ & 5.6 & $2.0^{\circ} \mathrm{C}$ & $\mathrm{F}$ & LL \\
\hline $\begin{array}{l}\text { Limsupavanich } \\
(2005)\end{array}$ & $\mathrm{D}$ & $\begin{array}{l}\text { HunterLab MiniScan } 囚 \text { XE } \\
\text { Spectrophotometer }\end{array}$ & $3.18 \mathrm{~cm}$ & 3 & $0,1,3,5$ & NR & $\begin{array}{l}5.50 \\
5.80\end{array}$ & $0.0^{\circ} \mathrm{C} \pm 3.0^{\circ} \mathrm{C}$ & $\mathrm{F}$ & LL, PM \\
\hline Abraham et al. (2017) & $\mathrm{J}$ & 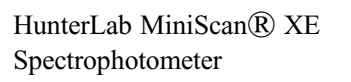 & $2.50 \mathrm{~cm}$ & 2 & $0,1,3,5,7$ & $2.50 \mathrm{~cm}$ & $\begin{array}{l}5.61 \\
5.72\end{array}$ & $2.0^{\circ} \mathrm{C} \pm 1.0^{\circ} \mathrm{C}$ & $\mathrm{F}$ & LL, PM \\
\hline Nair et al. (2018) & $\mathrm{J}$ & $\begin{array}{l}\text { HunterLab LabScan XE } \\
\text { Colorimeter }\end{array}$ & $2.54 \mathrm{~cm}$ & 3 & $0,3,6$ & $1.92 \mathrm{~cm}$ & NR & $2.0^{\circ} \mathrm{C}$ & $\mathrm{D}$ & LL, PM \\
\hline Joseph et al. (2012) & $\mathrm{J}$ & $\begin{array}{l}\text { HunterLab LabScan XE } \\
\text { Colorimeter }\end{array}$ & $2.54 \mathrm{~cm}$ & 4 & $0,5,9$ & $2.54 \mathrm{~cm}$ & $\begin{array}{l}5.53 \\
5.66\end{array}$ & $2.0^{\circ} \mathrm{C}$ & $\mathrm{F}$ & LL, PM \\
\hline Phelps et al. (2014) & $\mathrm{J}$ & HunterLab MiniScan ${ }^{\mathrm{TM}} \mathrm{EZ}$ & $2.54 \mathrm{~cm}$ & 3 & $\begin{array}{c}0,2,4,5 \\
\quad 6,7\end{array}$ & $2.54 \mathrm{~cm}$ & 5.61 & $3.0^{\circ} \mathrm{C} \pm 2.0^{\circ} \mathrm{C}$ & $\mathrm{F}$ & LL \\
\hline Phelps et al. (2016) & $\mathrm{J}$ & HunterLab MiniScan ${ }^{\mathrm{TM}}$ EZ & $2.54 \mathrm{~cm}$ & 3 & $\begin{array}{l}0,1,2,3 \\
4,5,6,7\end{array}$ & $2.54 \mathrm{~cm}$ & 5.65 & $0.3^{\circ} \mathrm{C} \pm 0.9^{\circ} \mathrm{C}$ & $\mathrm{F}$ & LL \\
\hline Purohit et al. (2015) & $\mathrm{J}$ & HunterLab MiniScan ${ }^{\mathrm{TM}} \mathrm{EZ}$ & $2.54 \mathrm{~cm}$ & 3 & $1,5,9$ & $2.54 \mathrm{~cm}$ & $\begin{array}{l}5.82 \\
5.85\end{array}$ & $2.0^{\circ} \mathrm{C} \pm 1.0^{\circ} \mathrm{C}$ & $\mathrm{F}$ & LL, PM \\
\hline $\begin{array}{l}\text { Ramanathan et al. } \\
\text { (2011) }\end{array}$ & $\mathrm{J}$ & $\begin{array}{l}\text { HunterLab MiniScan } ® \text { XE } \\
\text { Plus Spectrophotometer }\end{array}$ & $2.54 \mathrm{~cm}$ & 3 & $0,5,13$ & $1.91 \mathrm{~cm}$ & 5.60 & $1.0^{\circ} \mathrm{C}$ & $\mathrm{D}$ & LL \\
\hline $\begin{array}{l}\text { Ramanathan et al. } \\
\text { (2018) }\end{array}$ & $\mathrm{J}$ & $\begin{array}{l}\text { HunterLab MiniScan } ® \text { XE } \\
\text { Plus Spectrophotometer }\end{array}$ & $2.50 \mathrm{~cm}$ & 2 & $0,1,2,3$ & $2.50 \mathrm{~cm}$ & 5.60 & $2.0^{\circ} \mathrm{C} \pm 1.0^{\circ} \mathrm{C}$ & $\mathrm{F}$ & LL \\
\hline Mancini et al. (2018) & $\mathrm{J}$ & HunterLab Miniscan XE Plus & $2.54 \mathrm{~cm}$ & $2-3$ & $\begin{array}{l}0,1,2,3 \\
4,5,6\end{array}$ & $2.54 \mathrm{~cm}$ & NR & $4.0^{\circ} \mathrm{C}$ & $\mathrm{F}$ & LL, PM \\
\hline King et al. (2011a) & $\mathrm{J}$ & $\begin{array}{l}\text { HunterLab MiniScan } 囚 \text { XE } \\
\text { Plus Spectrophotometer }\end{array}$ & $25 \mathrm{~mm}$ & 2 & $0,1,3,6,9$ & $2.54 \mathrm{~cm}$ & 5.59 & $1.0^{\circ} \mathrm{C}$ & $\mathrm{F}$ & LL \\
\hline Kim et al. (2016) & $\mathrm{J}$ & HunterLab MiniScan ${ }^{\mathrm{TM}} \mathrm{EZ}$ & $25 \mathrm{~mm}$ & 3 & $1,4,7$ & $2.50 \mathrm{~cm}$ & NR & $2.5^{\circ} \mathrm{C}$ & $\mathrm{F}$ & LL \\
\hline $\begin{array}{l}\text { McKenna et al. } \\
(2005)\end{array}$ & $\mathrm{J}$ & $\begin{array}{l}\text { HunterLab MiniScan } \AA \text { XE } \\
\text { Plus }\end{array}$ & $31.8 \mathrm{~mm}$ & 3 & $\begin{array}{l}0,1,2,3 \\
4,5,6\end{array}$ & $2.54 \mathrm{~cm}$ & $\begin{array}{l}5.77 \\
5.73\end{array}$ & $2.2^{\circ} \mathrm{C} \pm 2^{\circ} \mathrm{C}$ & $\mathrm{F}$ & LL, PM \\
\hline Canto et al. (2016) & $\mathrm{J}$ & $\begin{array}{l}\text { CM-600D, Konica Minolta } \\
\text { Sensing }\end{array}$ & $8 \mathrm{~mm}$ & 3 & $0,3,6,9$ & $2.54 \mathrm{~cm}$ & 5.52 & $4.0^{\circ} \mathrm{C}$ & NR & LL, PM \\
\hline Wu et al. (2020) & $\mathrm{J}$ & Model SP62, X-Rite, Inc & $8 \mathrm{~mm}$ & 4 & $0,3,5,7$ & $2.50 \mathrm{~cm}$ & 5.53 & $2.0^{\circ} \mathrm{C} \pm 1.0^{\circ} \mathrm{C}$ & LED & LL \\
\hline $\begin{array}{l}\text { Najar-Villarreal et al. } \\
(2021)\end{array}$ & $\mathrm{J}$ & HunterLab MiniScan ${ }^{\mathrm{TM}}$ EZ & $2.54 \mathrm{~cm}$ & 3 & $\begin{array}{l}0,3,6,9 \\
12,15\end{array}$ & $2.54 \mathrm{~cm}$ & 5.56 & $0.0^{\circ} \mathrm{C} \pm 4.0^{\circ} \mathrm{C}$ & $\mathrm{F}$ & LL \\
\hline Sakomoto (2017) & $\mathrm{D}$ & $\begin{array}{l}\text { HunterLab MiniScan } \AA \text { XE } \\
\text { Plus }\end{array}$ & $2.50 \mathrm{~cm}$ & 3 & $0,2,3,4,6$ & $2.00 \mathrm{~cm}$ & $\begin{array}{l}5.34- \\
5.58\end{array}$ & $3.0^{\circ} \mathrm{C} \pm 1.0^{\circ} \mathrm{C}$ & $\mathrm{F}$ & LL \\
\hline
\end{tabular}


Table 1. (Continued)

\begin{tabular}{|c|c|c|c|c|c|c|c|c|c|c|}
\hline Author(s) & Source $^{2}$ & Colorimeter & $\begin{array}{l}\text { Aperture } \\
\text { size }\end{array}$ & Scans $^{3}$ & $\begin{array}{l}\text { Display } \\
\text { days }\end{array}$ & $\begin{array}{c}\text { Steak } \\
\text { thickness }\end{array}$ & $\mathrm{pH}^{4}$ & $\begin{array}{c}\text { Temperature } \\
{ }^{\circ} \mathrm{C}^{5} \\
\end{array}$ & $\begin{array}{c}\text { Lighting } \\
\text { type }^{6}\end{array}$ & Muscle $^{1}$ \\
\hline$\overline{\text { Phelps et al. (2020) }}$ & $\bar{J}$ & HunterLab MiniScan ${ }^{\mathrm{TM}} \mathrm{EZ}$ & $2.54 \mathrm{~cm}$ & 3 & $\begin{array}{c}0,1,2,3 \\
4,5,6,7, \\
8,9,10\end{array}$ & $2.54 \mathrm{~cm}$ & NR & $2.0^{\circ} \mathrm{C} \pm 1.0^{\circ} \mathrm{C}$ & $\mathrm{F}$ & $\overline{\mathrm{LL}}$ \\
\hline Canto et al. (2015) & $\mathrm{J}$ & 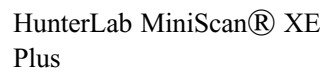 & $2.54 \mathrm{~cm}$ & 2 & 0,11 & $2.54 \mathrm{~cm}$ & 5.70 & $1.0^{\circ} \mathrm{C}$ & $\mathrm{F}$ & LL \\
\hline King et al. (2011b) & $\mathrm{J}$ & 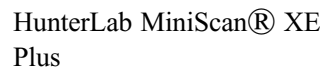 & $25 \mathrm{~mm}$ & 2 & $\begin{array}{l}0,1,2,3 \\
\quad 4,5,6\end{array}$ & $2.54 \mathrm{~cm}$ & 5.58 & $1.0^{\circ} \mathrm{C}$ & $\mathrm{F}$ & LT \\
\hline Kim et al. (2009) & $\mathrm{J}$ & 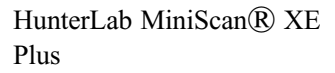 & $31.8 \mathrm{~mm}$ & 3 & $\begin{array}{l}0,1,2,3 \\
4,5,6,7\end{array}$ & $2.54 \mathrm{~cm}$ & $\begin{array}{l}5.71 \\
5.73\end{array}$ & $1.0^{\circ} \mathrm{C}$ & $\mathrm{F}$ & LL, PM \\
\hline
\end{tabular}

${ }^{1}$ Muscles used in this study: $\mathrm{LL}=$ longissimus lumborum; $\mathrm{PM}=$ psoas major.

${ }^{2}$ Source of data: $\mathrm{D}=$ dissertation; $\mathrm{J}=$ peer-review journal.

${ }^{3}$ Number of scans per steak within the study.

${ }^{4} \mathrm{The} \mathrm{pH}$ average of muscles: $\mathrm{LT}=$ longissimus thoracis; $\mathrm{PM}=$ psoas major.

${ }^{5}$ Temperature of simulated retail display.

${ }^{6}$ Type of lighting used during retail display: $\mathrm{D}=$ dark; $\mathrm{F}=$ fluorescence; $\mathrm{LED}=$ light emitting diode; $\mathrm{N}=$ natural.

$\mathrm{NR}=$ not reported

5 categories: $0-7 \mathrm{~d}, 8-14 \mathrm{~d}, 15-21 \mathrm{~d}, 22-28 \mathrm{~d}$, and 29-65 d. Each category consisted of 5 to 16 experiments, totaling 48 experiments. For PM steaks, the actual postmortem aging times were grouped into 2 categories: 0-7 d and 8-21 d. Each category consisted of 11 and 5 experiments, respectively. The total display day observations for LL and PM were 255 and 71 , respectively.

\section{Selection criteria for inclusion and exclusion}

In order to be included in the final database for LL and PM, experiments had to meet the following criteria: (1) colorimeter type, (2) aperture size, (3) number of scans, (4) display days, (5) steak thickness, (6) $\mathrm{pH}$ of meat, (7) storage temperature, (8) objective color measures, (9) subjective color measures, (10) oxygenpermeable packaging (polyvinyl chloride) or modified atmosphere packaging with $80 \% \mathrm{O}_{2}$ and $20 \% \mathrm{CO}_{2}$, and (11) lighting type. Studies evaluating the effect of enhancement solutions on LL meat color were considered for this study. In addition to these parameters, the variable postmortem aging time was included, and studies evaluating the effect of enhancements or other packaging different than oxygen-permeable packaging for LL and PM steaks were not considered for phase 2 . To estimate $a^{*}$ redness values, studies assessing meat color using a colorimeter with illuminant A were excluded if visual color data were not reported in hedonic scales. Furthermore, experiments had to provide display day means and SEM had to be included in the meta-analysis.

\section{Statistical analysis}

Statistical analysis was performed using SAS version 9.4 (SAS Institute, Inc., Cary, NC) PROC MIXED. The inverse variance weighting in metaanalysis was carried out via the WEIGHT statement followed by a variable equal to the inverse of the variance of the reported mean response. The phase 1 analysis implemented a hierarchical linear model (Singer, 1998; Sullivan et al. 1999), with the reported $a^{*}$ mean being the response variable and the $a^{*}$ mean being the linear regressor (i.e., fixed effect). Experiment was defined as the combination of paper, actual postmortem aging time, and study repeat. There were 29 experiments for LL steaks and 6 experiments for PM steaks. The model contained 3 random components: 2 represented the variation of intercept and slope at the experiment level, and the third represented the random error at the display-day-by-experiment level. The variancecovariance of the intercept and slope was taken as unstructured. The phase 2 analysis implemented a hierarchical linear model with display day and postmortem aging time being the regressors. Fixed effects of the model included postmortem aging group (a categorical variable), display day (linear effect of a numeric variable), display day squared (quadratic effect of a numeric variable), interactions of postmortem aging group with display day (linear effect heterogeneous with respect to postmortem aging group), and interaction of postmortem aging group and display day squared (i.e., quadratic effects heterogeneous with respect to postmortem aging group). The model contained 4 random components: 3 represented 
the variation of intercept, linear coefficient, and quadratic coefficient at the experiment level; the fourth represented the random error at the display-day-byexperiment level. The variance-covariance of regression coefficients were taken as unstructured. Only $a^{*}$ redness was included in the model because all studies reported this measure. Using a confidence interval of $95 \%$, the $a^{*}$ threshold was calculated using 5.9 and 3.5 using illuminant A for LL and PM muscles, respectively.

\section{Results and Discussion}

\section{Phase 1}

The estimates for $a^{*}$ redness using 5.9 and 3.5 as a borderline acceptability for color life of LL and PM steaks with a $95 \%$ confidence interval can be found in Table 2. For LL steaks, the $a^{*}$ values for borderline acceptability estimated in phase 1 for LL were 22.15 for the estimate and 24.07 and 20.24 for the higher and lower bounds, respectively, for $a^{*}$ redness using a $95 \%$ confidence interval. In addition, the $a^{*}$ values for borderline acceptability for PM steaks were 22.37 for the estimate and 23.75 and 20.99 for the higher and lower bounds, respectively, for $a^{*}$ redness using a $95 \%$ confidence interval. It has been previously reported that for a response known to decrease over time, the lower one-sided $95 \%$ confidence limit should be used (U.S. Department of Health and Human ServicesFDA-Center for Veterinary Medicine, 2014). Thus, the $a^{*}$ color value lower bounds-20.24 and 20.99were selected as borderline acceptability for LL and $\mathrm{PM}$, respectively. By observing the linear trend and the normality assumption in Figures 1 and 2, the adequacy of the model for LL and PM, respectively, for phase 1, can be inferred. The plots of residuals versus predicted values (Figure 1, plot a) and (Figure 2, plot c) were analyzed and suggest that a linear trend with a constant variance was reasonable, indicating that the estimations calculated were precise for LL and PM steaks, respectively, for phase 1 . In addition, the studentized residuals

Table 2. Estimations ${ }^{1}$ for $a^{*}$ redness using illuminant A for discoloration for longissimus lumborum (LL) and psoas major (PM) steaks, respectively

\begin{tabular}{lccc}
\hline \hline Measurement & Estimate & Lower Bound & Upper Bound \\
\hline LL & 22.15 & 20.24 & 24.07 \\
PM & 22.37 & 20.99 & 23.75 \\
\hline
\end{tabular}

${ }^{1}$ These values were estimated using a $95 \%$ confidence interval.

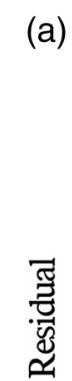

(a)
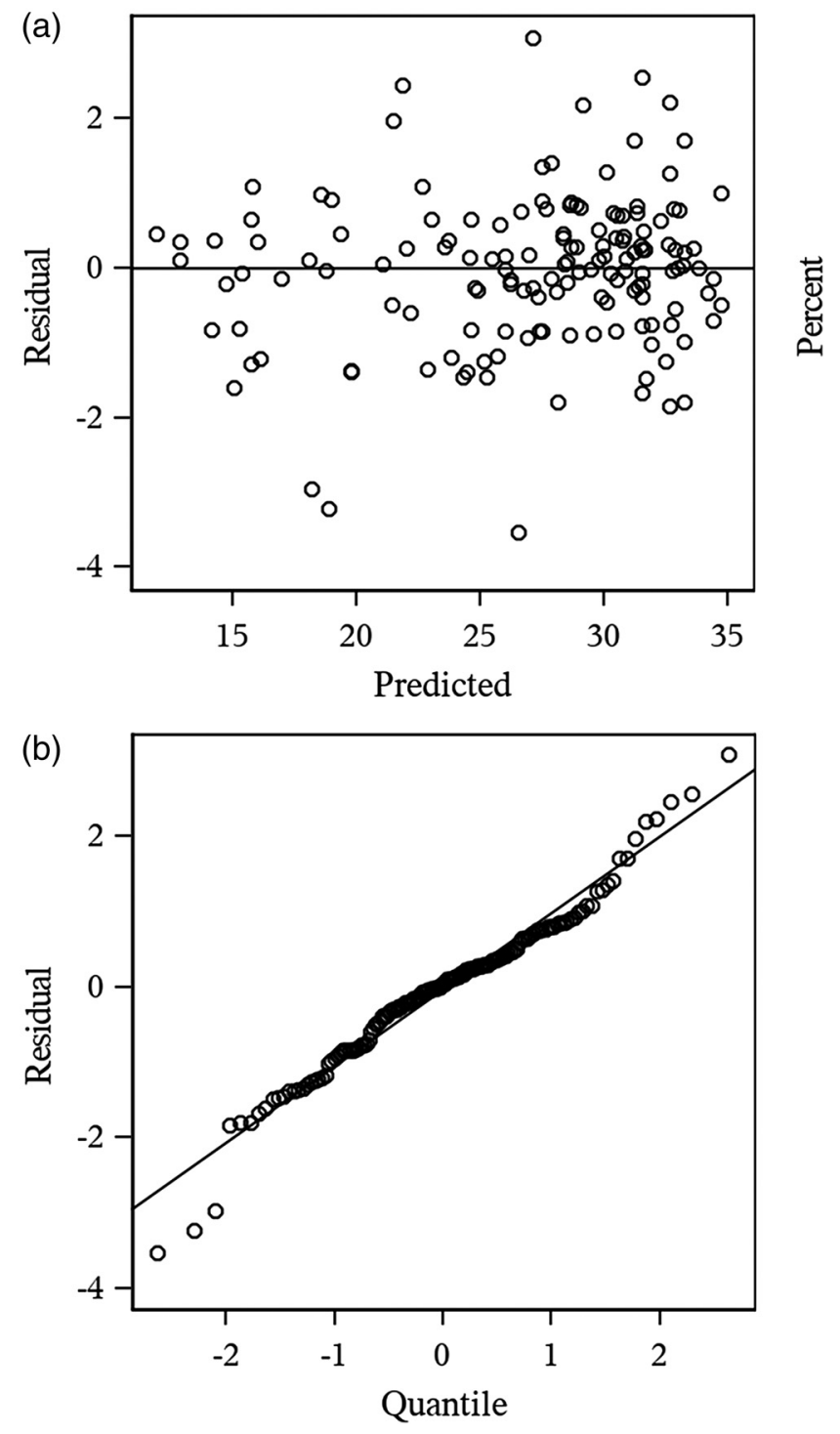

Figure 1. Plots of residual versus predicted values relative to the line of distribution (a) and studentized residual (b) of $a^{*}$ redness for longissimus lumborum for phase 1 .

plots (Figure 1, plot b) and (Figure 2, plot d) suggest that the normality assumption was met and no evidence for outliers and heteroscedasticity was observed for LL and PM.

Historically, LL (also known as the strip loin) is a heavily researched muscle, and it is widely used in the meat science literature. Overall, this muscle provides a good lean tissue area to be assessed by researchers. As a result, a great number of referred journal articles for LL were found in the literature compared with the number found for the PM muscle. These 2 muscles are popular among consumers and are normally found in display cases at the retail level.

Simulated retail display time ranged from $0 \mathrm{~d}$ to $15 \mathrm{~d}$ among all experiments. Temperature averages 

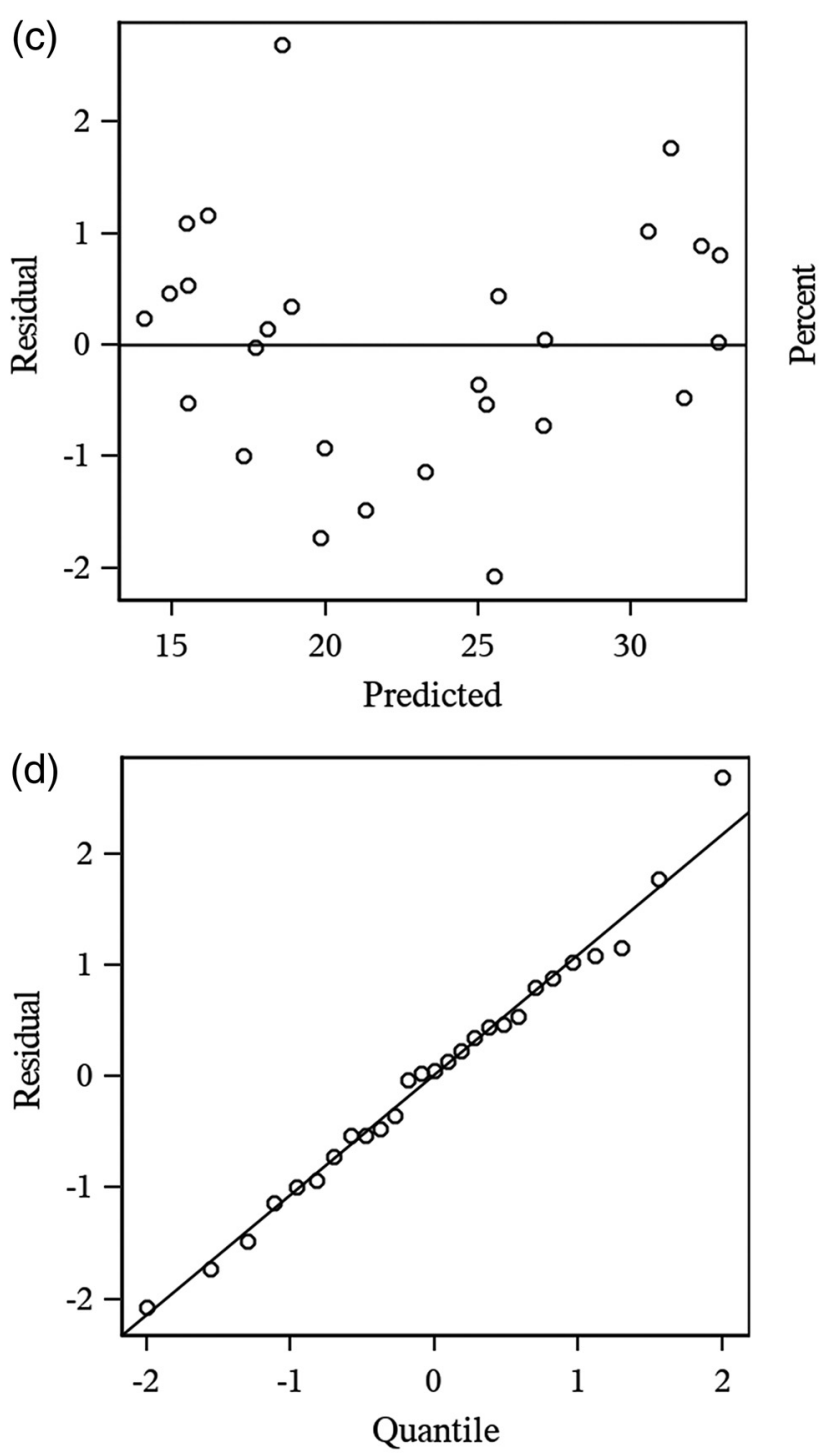

Figure 2. Plots of residual versus predicted values relative to the line of distribution (c) and studentized residual (d) of $a^{*}$ redness for psoas major for phase 1 .

for simulated display studies were $-3^{\circ} \mathrm{C}$ to $7^{\circ} \mathrm{C}$. Mancini et al. (2002) conducted a national retail survey and reported an average display case temperature of $4.4^{\circ} \mathrm{C}$ at retail. The $\mathrm{pH}$ of $\mathrm{LL}$ and $\mathrm{PM}$ steaks ranged from 5.50 to 5.82 in the papers used in this study. To objectively assess the color of fresh meat, colorimeters or spectrophotometers such as the Minolta-branded instrument (Chiyoda-ku, Tokyo, Japan) or the Hunter Associates Laboratory instrument (Reston, VA) have been used in 644 and 339 articles, respectively (Tapp et al., 2011). Some of the specifications that can be used to assess color on meat products are illuminant A, C, and D65, which measure tristimulus values, including $L^{*}$, $a^{*}$, and $b^{*}$. Upon the completion of the search of meat color papers, nearly $50 \%$ (data not shown) were journal articles reporting data using illuminant D65 and/or C, but these data are not comparable with illuminant A. The light source or type of illuminant plays an important role in the color being measured on meat and meat products, and the American Meat Science Association (AMSA, 2012) color guidelines recommend the use of illuminant A owing to the higher proportion of long, red wavelengths, which have been determined to have higher correlations with visual color scores. It is noteworthy to mention that $a^{*}$ was reported in the literature in higher proportion compared with $L^{*}$ and $b^{*}$.

It has been previously reported that there were some inconsistencies in publications when apparatus specifications were reported, and some authors failed to thoroughly describe the essential specifications when assessing meat color as recommended by the AMSA (2012) Meat Color Measurement Guidelines. For instance, Tapp et al. (2011) conducted a survey of 1,068 published (1998 to 2007) manuscripts and found that $3 \%$ of studies failed to include instrument type, $52.4 \%$ failed to report number of scans on each sample, and $73.6 \%$ failed to include aperture size. The number scans reported in the experiments used in this analysis ranged from 2 to 4 scans per sample. In addition, a standardized method to visually assess beef color was not observed across the experiments reviewed for this study; researchers used hedonic and $100 \%$ scales interchangeably in their results. Because this meta-analysis followed AMSA (2012) color guidelines, papers using other types of visual color scales were not comparable to one another and were excluded.

Estimations for the meta-analysis were calculated using visual color scores and $a^{*}$ instrumental color data from papers using illuminant A. In past literature, metmyoglobin formation or discoloration on the surface of $20 \%$ has been widely used in the literature as an acceptable color threshold to determine borderline acceptability using instrumental color results (Hood and Riordan, 1973). It is noteworthy to mention that this research was published more than 50 years ago. Therefore, the estimations calculated in this study represent the most current data published within the last 20 years (2000 to 2020). Additionally, they reflect current beef production practices and may indicate the length of time that aerobically packaged LL and PM steaks have acceptable color. The borderline thresholds estimated using the present data set may only be used for LL and PM, whereas other meta-analyses should be performed for other muscles depending upon the literature that is available. 


\section{Phase 2}

Several studies have shown that antemortem factors can affect meat color, including age, sex, genetics, and nutrition (Faustman and Cassens, 1990; Suman and Joseph, 2013). Meat scientists conducting meat color research using high forage/grass feeding systems have found that the meat produced uses energy differently (more oxidative) and can result in darker lean meat (Muir et al., 1998; Vestergaard et al., 2000). It is well established that the ultimate $\mathrm{pH}$ of meat plays a role in meat color. Generally, high-pH meat is biochemically different and has shown increased oxygen consumption than normal-pH meat (English et al., 2016). Thus, those experiments using high-pH treatments were excluded from the meta-analysis. Overall, most of the meat used in the current studies was procured and sourced from a commodity cattle production system in the US, which are primarily cattle finished on a concentrate diet.

To date, meat packers utilize postmortem aging time as means to guarantee tenderness, and $14 \mathrm{~d}$ of postmortem aging time is a meat industry standard to ensure a good consumer eating experience; however, undergoing postmortem aging time that exceeds $14 \mathrm{~d}$ may lead to poor color stability (Ramanathan et al., 2020). English et al. (2016) compared LL aged 21, 42 , and $62 \mathrm{~d}$ and reported that extended aging had a detrimental effect on color stability during retail display. They demonstrated that LL steaks with $>42 \mathrm{~d}$ of postmortem aging time bloomed less than LL steaks with $21 \mathrm{~d}$ postmortem aging time and deducted that this lack of blooming was due to the increased purge loss containing myoglobin during postmortem aging time (English et al., 2016). In addition, these authors reported that extended aging increased oxygen consumption, which may influence the consumer-preferred red color of beef. Postmortem strategies to optimize the color life of fresh meat are key throughout the supply chain. Other exogenous factors influencing beef color are storage, display conditions, packaging, and the addition of antioxidants, among others (Faustman and Cassens, 1990; Mancini and Hunt, 2005; Suman and Joseph, 2013). For phase 2, papers that included beef packaged in polyvinyl chloride film and modified atmosphere packaging $80 \% \mathrm{O}_{2} / 20 \% \mathrm{CO}_{2}$ were used for the metaanalysis, but other types of modified atmosphere packaging such as $\mathrm{CO}$ were excluded.

Plots of residuals versus predicted values and studentized residuals plots can be observed in Figure 3 for LL for phase 2 . The residuals versus predicted values plot (Figure 3, plot e) indicates that a linear trend with a
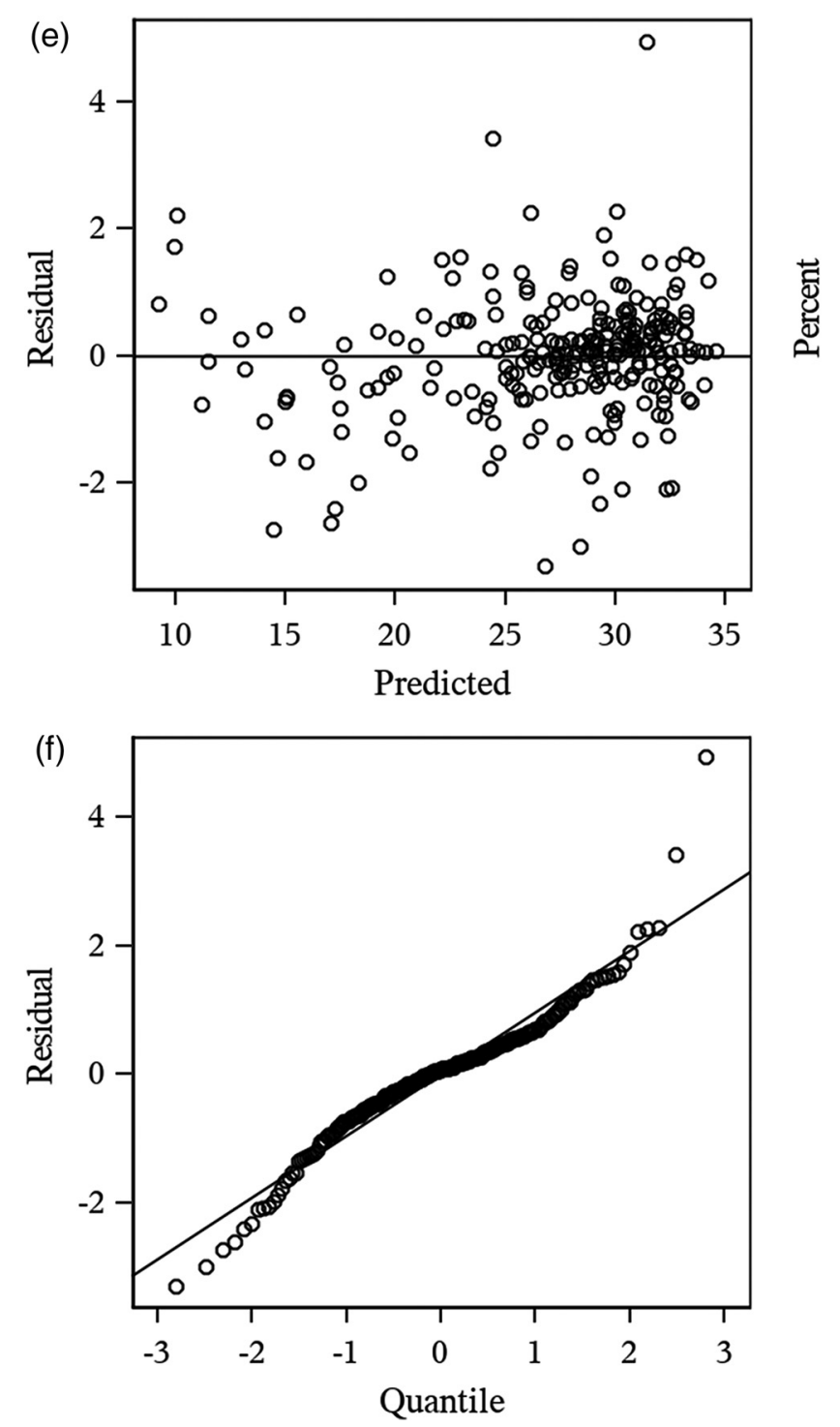

Figure 3. Plots of residual versus predicted values relative to the line of distribution (e) and studentized residual (f) of $a^{*}$ redness for longissimus lumborum for phase 2 .

constant variance is reasonable and (Figure 3, plot $\mathrm{f}$ ) indicates that the normal assumption about the errors is reasonable as well. The residuals versus predicted values (plot g) and studentized residuals plots (plot $\mathrm{h}$ ) for PM can be found in Figure 4. An outlier in the studentized residuals plots and line of distribution for the PM in phase 2 was observed. Having one value as an outlier is not preferred but still is important to include all values in the model regardless of how far they are from all data points. As a following step, these estimates will be challenged in a validation color life study using the LL and PM muscles at different postmortem aging times to assess our model.

The estimates of color life of LL steaks during retail display are shown in Figure 5. The $a^{*}$ value used 

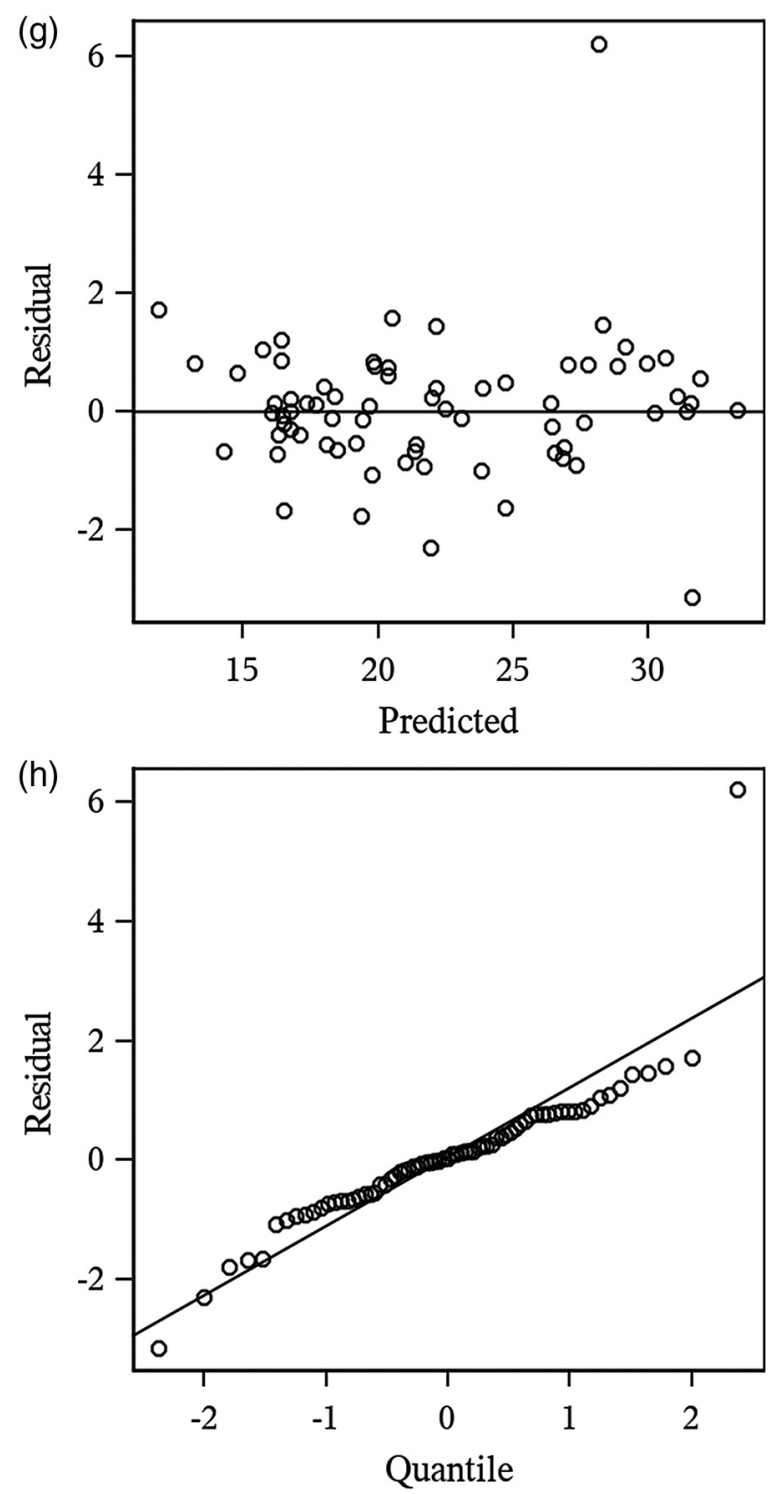

Figure 4. Plots of residual versus predicted values relative to the line of distribution ( $\mathrm{g}$ ) and studentized residual (h) of $a^{*}$ redness for psoas major for phase 2 .

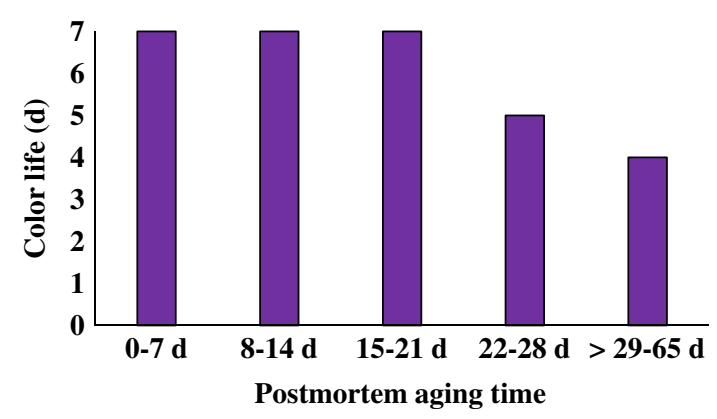

Figure 5. Estimates of color life of longissimus lumborum steaks during retail display using $a^{*}$ redness scores.

for LL was 20.24. The first $21 \mathrm{~d}$ of postmortem aging time (storage before display) were found to have the longest color life, with $7 \mathrm{~d}$ of color life for LL steaks.

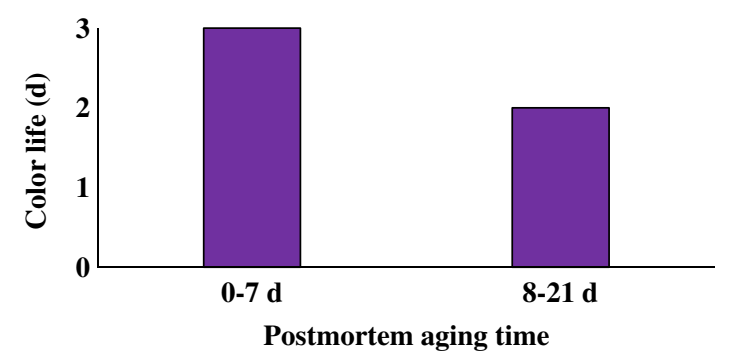

Figure 6. Estimates of color life of psoas major steaks during retail display using $a^{*}$ redness scores.

Additionally, the color life of LL steaks with postmortem aging time 29-65 $\mathrm{d}$ and 22-28 $\mathrm{d}$ was 5 and $4 \mathrm{~d}$, respectively. For PM, the estimates of color life of LL are shown in Figure 6. The estimated time before borderline acceptability for 0 - to 7 -d postmortem aging time was $3 \mathrm{~d}$ for PM steaks. The color life of PM steaks with 8 to $21 \mathrm{~d}$ of postmortem aging time was only $2 \mathrm{~d}$. Colle et al. (2015) reported the same decline in redness color life of LL steaks for extended postmortem aging time. They reported that $a^{*}$ values of LL steaks decreased during simulated retail display when strip loins were aged $14 \mathrm{~d}$ or longer. In addition, English et al. (2016) compared LL aged 21, 42, and $62 \mathrm{~d}$ and reported that extended aging had a detrimental effect on color stability during retail display.

\section{Conclusions}

These estimations may be applicable when procuring commodity meat with a normal $\mathrm{pH}$ from a grain feeding system. There were some limitations, including few papers available in the literature and an outlier for the PM data. Using meat produced from cattle raised under different feeding systems,- - primarily grass-fed, which is typically found in other countriesmay not provide an accurate estimation owing to their inherent color differences. Overall, knowing the postmortem age of LL and PM subprimals could serve as a tool for retailers to identify the potential display color life of LL and PM steaks displayed under aerobic packaging conditions. Estimations calculated using trained panel data and $a^{*}$ redness values retrieved from this meta-analysis demonstrate that using LL and PM subprimals that have a postmortem aging time age of $21 \mathrm{~d}$ or less and $7 \mathrm{~d}$ or less, respectively, would optimize the retail display color life of aerobically packaged steaks.

\section{Literature Cited}

Abraham, A., J. W. Dillwith, G. G. Mafi, D. L. VanOverbeke, and R. Ramanathan. 2017. Metabolite profile differences between 
beef longissimus and psoas muscles during display. Meat Muscle Biol. 11:18-27. https://doi.org/10.22175/mmb2016. 12.0007 .

AMSA. 2012. Meat color measurement guidelines. Am. Meat Sci. Assoc., Chicago, IL.

Canto, A. C., B. R. Costa-Lima, S. P. Suman, M. L. G. Monteiro, F. M. Viana, A. P. A. Salim, M. N. Nair, T. J. P. Silva, and C. A. Conte-Junior. 2016. Color attributes and oxidative stability of longissimus lumborum and psoas major muscles from Nellore bulls. Meat Sci. 121:19-26. https://doi.org/10.1016/j.meatsci. 2016.05.015.

Canto, A. C., S. P. Suman, M. N. Nair, S. Li, G. Rentfrow, C. M. Beach, T. J. P. Silva, T. L. Wheeler, S. D. Shackelford, A. Grayson, R. O. McKeith, and D. A. King. 2015. Differential abundance of sarcoplasmic proteome explains animal effect on beef Longissimus lumborum color stability. Meat Sci. 102:90-98. https://doi.org/10.1016/j.meatsci.2014.11.011.

Carpenter, C. E., D. P. Cornforth, and D. Whittier. 2001. Consumer preferences for beef color and packaging did not affect eating satisfaction. Meat Sci. 57:359-363. https://doi.org/10.1016/ S0309-1740(00)00111-X.

Colle, M. J., R. P. Richard, K. M. Killinger, J. C. Bohlscheid, A. R. Gray, W. I. Loucks, R. N. Day, A. S. Cochran, J. A. Nasados, and M. E. Doumit. 2015. Influence of extended aging on beef quality characteristics and sensory perception of steaks from the gluteus medius and longissimus lumborum. Meat Sci. 110:32-39. https://doi.org/10.1016/j.meatsci.2015.06.013.

Daniel, M. J., M. E. Dikeman, A. M. Arnett, and M. C. Hunt. 2009. Effects of dietary vitamin A restriction during finishing on color display life, lipid oxidation, and sensory traits of longissimus and triceps brachii steaks from early and traditionally weaned steers. Meat Sci. 81:15-21.

Guelker, M. R., A. N. Haneklaus, J. C. Brooks, C. C. Carr, R. J. Delmore Jr., D. B. Griffin, D. S. Hale, K. B. Harris, G. G. Mafi, D. D. Johnson, C. L. Lorenzen, R. J. Maddock, J. N. Martin, R. K. Miller, C. R. Raines, D. L. VanOverbeke, L. L. Vedral, B. E. Wasser, and J. W. Savell, 2013. National Beef Tenderness Survey-2010: Warner-Bratzler shear force values and sensory panel ratings for beef steaks from United States retail and food service establishments. J. Anim. Sci. 91:1005-1014. https://doi.org/10.2527/jas. 2012-5785.

English, A. R. 2015. Effects of extended aging on biochemical properties of dark cutting beef. M.S. dissertation, Oklahoma State Univ., Stillwater, OK. https://shareok.org/bitstream/ handle/11244/45162/English_okstate_0664M_13958.pdf? sequence $=1 \&$ isAllowed=y. (Accessed 10 October 2020).

English, A. R., G. G. Mafi, D. L. VanOverbeke, and R. Ramanathan. 2016. Effects of extended aging and modified atmospheric packaging on beef top loin steak color. J. Anim. Sci. 94:1727-1737. https://doi.org/10.2527/jas.2015-0149.

Faustman, C., and R. G. Cassens. 1990. The biochemical basis for discoloration in fresh meat: a review. J. Muscle Foods. 1:21743. https://doi.org/10.1111/j.1745-4573.1990.tb00366.x.

Gonzalez, J. M., S. E. Johnson, T. A. Thrift, J. D. Savell, S. E. Ouellette, and D. D. Johnson. 2009. Effect of ractopaminehydrochloride on the fiber type distribution and shelf-life of six muscles of steers. J. Anim. Sci. 87:1764-1771. https:// doi.org/10.2527/jas.2008-1469.
Grobbel, J. P., M. E. Dikeman, M. C. Hunt, and G. A. Milliken. 2008. Effects of packaging atmospheres on beef instrumental tenderness, fresh color stability, and internal cooked color. J. Anim. Sci. 86:1191-1199. https://doi.org/10.2527/jas.2007-0479.

Hood, D. E., and E. B. Riordan. 1973. Discolouration in prepackaged beef: Measurement by reflectance spectrophotometry and shopper discrimination. Int. J. Food Tech. 8:333343. https://doi.org/10.1111/j.1365-2621.1973.tb01721.x.

Hunt, M. C., R. A. Mancini, K. A. Hachmeister, D. H. Kropf, M. Merriman, G. De Lduca, and G. Milliken. 2004. Carbon monoxide in modified atmosphere packaging affects color, shelf life, and microorganisms of beef steaks and ground beef. J. Food Sci. 69:FCT45-FCT52. https://doi.org/10.1111/j. 1365-2621.2004.tb17854.x.

Hutchison, S. 2007. Improving the value of cull cows through antemortem management practices and postmortem enhancement technologies. Ph. D. dissertation, Kansas State Univ., Manhattan, KS. https://krex.k-state.edu/dspace/handle/2097/ 424. (Accessed 2 December 2020).

Joseph, P., S. P. Suman, G. Rentfrow, S. Li, and C. M. Beach. 2012. Proteomics of muscle-specific beef color stability. J. Agr. Food Chem. 60:3196-3203. https://doi.org/10.1021/jf204188v.

Kim, H. W., D. Setyabrata, Y. S. Choi, and Y. H. B. Kim. 2016. Rapid discoloration of aged beef muscles after short-term/ extreme temperature abuse during retail display. Korean J. Food Sci. Anim. Resources. 36:343. https://doi.org/10. 5851/kosfa.2016.36.3.343.

Kim, Y. H., M. C. Hunt, R. A. Mancini, M. Seyfert, T. M. Loughin, D. H. Kropf, and J. S. Smith. 2006. Mechanism for lactatecolor stabilization in injection-enhanced beef. J. Agr. Food Chem. 54:7856-7862. https://doi.org/10.1021/jf061225h.

Kim, Y. H., J. T. Keeton, S. B. Smith, L. R. Berghman, and J. W. Savell. 2009. Role of lactate dehydrogenase in metmyoglobin reduction and color stability of different bovine muscles. Meat Sci. 83:376-382. https://doi.org/10.1016/j.meatsci.2009.06.009.

King, D. A., S. D. Shackelford, and T. L. Wheeler. 2011a. Relative contributions of animal and muscle effects to variation in beef lean color stability. J. Anim. Sci. 895:1434-1451. https://doi. org/10.2527/jas.2010-3595.

King, D. A., S. D. Shackelford, A. B. Rodriguez, and T. L. Wheeler. 2011b. Effect of time of measurement on the relationship between metmyoglobin reducing activity and oxygen consumption to instrumental measures of beef longissimus color stability. Meat Sci. 87:26-32. https://doi.org/10.1016/j. meatsci.2010.08.013.

Kropf, D. H. 1993. Colour stability. Factors affecting the colour of fresh meat. Meat Focus International. 2:269-275.

Limsupavanich, R. 2005. Display color stability and myoglobin layer change of beef longissimus and psoas major steaks from various postmortem times. Ph. D. dissertation, Kansas State Univ., Manhattan, KS. (Accessed 15 December 2020).

Mancini, R. A., and Hunt, M. 2005. Current research in meat color. Meat Sci. 71:100-121. https://doi.org/10.1016/j.meatsci. 2005.03.003.

Mancini, R. A., K. Belskie, S. P. Suman, and R. Ramanathan. 2018. Muscle-specific mitochondrial functionality and its influence on fresh beef color stability. J. Food Sci. 83:2077-2082. https://doi.org/10.1111/1750-3841.14219. 
Mancini, R. A., M. C. Hunt, D. H. Kropf, K. A. Hachmeister, D. E. Johnson, and S. Fox. 2002. Maximizing desirable ground beef color with cold storage and display temperatures. Cattlemen's Day, Article 373. Kansas State University, Agricultural Experiment Station and Cooperative Extension Service. pp. 68-71. https://newprairiepress.org/cgi/viewcontent.cgi? article $=1776 \&$ context=kaesrr. (Accessed 4 February 2021).

Martinez, H. A., A. N. Arnold, J. C. Brooks, C. C. Carr, K. B. Gehring, D. B. Griffin, D. S. Hale, G. G. Mafi, D. D. Johnson, C. L. Lorenzen, R. J. Maddock, R. K. Miller, D. L. VanOverbeke, B. E. Wasser, and J. W. Savell. 2017. National Beef Tenderness Survey-2015: Palatability and shear force assessments of retail and foodservice beef. Meat Muscle Biol. 1(1). https://doi.org/10.22175/mmb2017.05. 0028 .

McKenna, D. R., P. D. Mies, B. E. Baird, K. D. Pfeiffer, J. W. Ellebracht, and J. W. Savell. 2005. Biochemical and physical factors affecting discoloration characteristics of 19 bovine muscles. Meat Sci. 70:665-682. https://doi.org/10.1016/j. meatsci.2005.02.016

Mitacek, R. M., A. R. English, G. G. Mafi, D. L. VanOverbeke, and R. Ramanathan. 2018. Modified atmosphere packaging improves surface color of dark-cutting beef. Meat Muscle Biol. 2:57-63. https://doi.org/10.22175/mmb2017. 04.0023 .

Muir, P., J. Deaker, and M. Bown. 1998. Effects of forage-and grain-based feeding systems on beef quality: a review. New Zeal. J. Agr. Res. 41:623-635. https://doi.org/10.1080/ 00288233.1998 .9513346$.

Nair, M. N., S. Li, C. M. Beach, G. Rentfrow, and S. P. Suman. 2018. Changes in the sarcoplasmic proteome of beef muscles with differential color stability during postmortem aging. Meat Muscle Biol. 2:1-17. https://doi.org/10.22175/ mmb2017.07.0037.

Najar-Villarreal, F., E. A. Boyle, T. A. Houser, C. I. Vahl, J. Wolf, J. M. Gonzalez, Q. Kang, J. Amamcharla, D. Vega, J. J. Kastner, and M. K. Cox. 2021. Correlation of bioelectrical impedance with freshness quality attributes of beef longissimus lumborum steaks. Meat Muscle Biol. 5:19. https://doi. org/10.22175/mmb.11704.

Phelps, K. J., J. S. Drouillard, J. S. Jennings, B. E. Depenbusch, C. L. Van Bibber-Krueger, K. A. Miller, M. A. Vaughn, D. D. Burnett, S. M. Ebarb, T. A. Houser, S. E. Johnson, and J. M. Gonzalez. 2014. Effects of the Programmed Nutrition Beef Program on meat quality characteristics. J. Anim. Sci. 92:1780-1791. https://doi.org/10.2527/jas.2013-7231.

Phelps, K. J., J. S. Drouillard, T. G. O'Quinn, T. A. Houser, and J. M. Gonzalez. 2020. Effects of supplementing docosahexaenoic acid-rich microalgae and antioxidants on beef longissimus lumborum steak color stability and sensory characteristics. Trans. Anim. Sci. 4:txaa135. https://doi.org/10.1093/tas/txaa135.

Phelps, K. J., J. S. Drouillard, T. G. O’Quinn, D. D. Burnett, T. L. Blackmon, J. E. Axman, C. L. Van Bibber-Krueger, and J. M. Gonzalez. 2016. Feeding microalgae meal (All-G Rich; CCAP 4087/2) to beef heifers. I: Effects on longissimus lumborum steak color and palatability. J. Anim. Sci. 94:40164029 .

Purohit, A., R. Singh, W. Kerr, and A. Mohan. 2015. Effects of heme and nonheme iron on meat quality characteristics during retail display and storage. J. Food Meas. Charact. 9:175-185. https://doi.org/10.1007/s11694-015-9222-y.

Ramanathan, R., M. C. Hunt, R. A. Mancini, M. N. Nair, M. L. Denzer, S. P. Suman, and G. G. Mafi. 2020. Recent updates in meat color research: integrating traditional and highthroughput approaches. Meat Muscle Biol. 4(2). https://doi. org/org/10.22175/mmb.9598.

Ramanathan, R., R. A. Mancini, and G. A. Dady. 2011. Effects of pyruvate, succinate, and lactate enhancement on beef longissimus raw color. Meat Sci. 88:424-428. https://doi.org/10. 1016/j.meatsci.2011.01.021.

Ramanathan, R., R. M. Mitacek, S. D. Billups, R. Jadeja, M. M. Pfeiffer, G. G. Mafi, and D. L. VanOverbeke. 2018. Novel nitrite-embedded packaging improves surface redness of dark-cutting longissimus steaks. Trans. Anim. Sci. 2:135143. https://doi.org/10.1093/tas/txy006.

Rogers, H. R., J. C. Brooks, M. C. Hunt, G. G. Hilton, D. L. VanOverbeke, J. Killefer, T. E. Lawrence, R. J. Delmore, B. J. Johnson, D. M. Allen, M. N. Streeter, W. T. Nichols, H. P. Hutcheson, D. A. Yates, J. N. Martin, and M. F. Miller. 2010. Effects of zilpaterol hydrochloride feeding duration on beef and calf-fed Holstein strip loin steak color. J. Anim. Sci. 88:1168-1183. https://doi.org/10.2527/jas.20092369.

Sakomoto, T. 2017. Effects of enhancement on beef longissimus color Master of Science, dissertation, Oklahoma State Univ., Stillwater, OK. https://shareok.org/bitstream/handle/11244/ 325407/Belem_okstate_0664M_16687.pdf?sequence=1\&is Allowed=y. (Accessed 10 October 2020).

Seyfert, M., R. A. Mancini, M. C. Hunt, J. Tang, and C. Faustman. 2007. Influence of carbon monoxide in package atmospheres containing oxygen on colour, reducing activity, and oxygen consumption of five bovine muscles. Meat Sci. 75:432442. https://doi.org/10.1016/j.meatsci.2006.08.007.

Seyfert, M., R. A. Mancini, M. C. Hunt, J. Tang, C. Faustman, and M. Garcia. 2006. Color stability, reducing activity, and cytochrome c oxidase activity of five bovine muscles. J. Agr. Food Chem. 54:8919-8925. https://doi.org/10.1021/jf061657s.

Singer, J. D. 1998. Using SAS PROC MIXED to fit multilevel models, hierarchical models, and individual growth models. J. Educ. Behav. Stat. 23:323-355. https://doi.org/10.3102/ 10769986023004323.

Steele, K. S., M. J. Weber, E. A. E. Boyle, M. C. Hunt, A. S. Lobaton-Sulabo, C. Cundith, Y. H. Hiebert, K. A. Abrolat, J. M. Attey, S. D. Clark, D. E. Johnson, T. L. Roenbaugh. 2016. Shelf life of fresh meat products under LED or fluorescent lighting. Meat Sci. 117:75-84. https://doi.org/10.1016/j. meatsci.2016.02.032.

Sullivan, L. M., K. A. Dukes, and E. Losina. 1999. An introduction to hierarchical linear modelling. Stat. Med. 18:855-888. https://doi.org/10.1002/(SICI)1097-0258(19990415)18: $7<855:$ :AID-SIM117>3.0.CO;2-7.

Suman, S. P., and P. Joseph. 2013. Myoglobin chemistry and meat color. Annu. Rev. Food Sci. T. 4:79-99. https://doi.org/10. 1146/annurev-food-030212-182623.

Tapp III, W. N., J. W. S. Yancey, and J. K. Apple. 2011. How is the instrumental color of meat measured?. Meat Sci. 89:1-5. https://doi.org/10.1016/j.meatsci.2010.11.021. 
U.S. Department of Health and Human Services Food and Drug Administration Center for Veterinary Medicine. 2014. https://www.fda.gov/regulatory-information/search-fda-guidancedocuments/cvm-gfi-219-vich-gl51-statistical-evaluation-stabilitydata. (Accessed 1 October 2021).

Vestergaard, M., N. Oksbjerg, and P. Henckel. 2000. Influence of feeding intensity, grazing and finishing feeding on muscle fibre characteristics and meat colour of semitendinosus, longissimus dorsi and supraspinatus muscles of young bulls. Meat Sci. 54:177-185. https://doi.org/10.1016/S0309-1740 (99)00098-4.

Wu, S., X. Luo, X. Yang, D. L. Hopkins, Y. Mao, and Y. Zhang. 2020. Understanding the development of color and color stability of dark cutting beef based on mitochondrial proteomics. Meat Sci. 163:108046. https://doi.org/10.1016/j.meatsci. 2020.108046. 